\title{
TANGGUNGJAWABHUKUM DALAM KONTEKS PERBUATAN MELAWAN HUKUM TERHADAP TINDAK PIDANA KORUPSI
}

\author{
Nia Putriyana \\ Shintiya Dwi Puspita \\ Fakultas Hukum Universitas Katolik Parahyangan \\ Jl. Ciumbuleuit 94 Bandung \\ Email:nn.niaputriyana@gmail.com,syntyaa@gmail.com
}

\begin{abstract}
Liability (responsibility) in law term have twocontext that connecting each other, which is criminal liability and private liability. Coruption have two kinds of it, in private connect with a national loss and in criminal term connect with conduct that forbid by law cause the destructing impact to society prosperity and walfare, tort is being part of liability in corruption term. Yuridis normative aprroach with descriptive analytisis research method that use in this paper. Tort can become the foundation to ask private liability on corruption with fault or mistake in it. Formal and material are two conditions on tort term that will make criminal conduct being part of corruption.
\end{abstract}

Key words: liability (responsibility), tort, corruption

\begin{abstract}
Abstrak
Tanggungjawab dalam terminologihukum memiliki dua konteks yang saling berkaitan satu dengan lainnya yaitu konteks perdata dan pidana, begitu pula dengan tindak pidana korupsi memiliki kedua konteks ini. Korupsi pada tanggungjawab perdata berada pada ruang lingkup kerugian yang dialami oleh negara, pada ranah pidana tanggungjawab tersebut merupakan perbuatan yang dilarang oleh hukum karena dampaknya merusak terhadap kesejahteraan dan kemakmuran masyarakat. Kedua tanggungjawab tersebut dapat dilekatkan pada tindak pidana korupsi dengan adanya perbuatan melawan hukum yang menjadi dasar atau landasan dari perlekatannya. Penelitian ini menggunakan metode pendekatan normatif yuridis.Perbuatan melawan hukum dapat dijadikan sebagai dasar dalam meminta tanggungjawab keperdataan dalam suatu tindak pidana korupsi dengan ketentuan adanya suatu kesalahan, baik itu dilakukan dengan kesengajaan maupun kelalaian. Perbuatan melawan hukum dapat menjadi dasar pertanggungjawaban baik secara perdata maupun pidana dengan memenuhi dua syarat yang menjadi landasan suatu tindak pidana termasuk ke dalam ranah korupsi. Syarat tersebut yaitu secara formil dan materil.
\end{abstract}

Kata kunci: tanggungjawab, perbuatan melawan hukum, korupsi 


\section{Latar Belakang}

Hukum merupakan bagian dari perangkat kerja sistem sosial. Fungsi sistem sosial ini adalah mengintregasikan kepentingan anggota masyarakat, sehingga terciptanya suatu keadaan tertib. Hal ini mengakibatkan bahwa tugas hukum adalah mencapai keadilan, yaitu keserasian antara nilai kepentingan hukum (rechtszekerheid). ${ }^{1}$ Upaya intregrasi akan ketertiban dan keadilan memiliki keterkaitan dengan konsep kewajiban hukum yang diartikan dengan konsep tanggungjawab hukum (liability). Seseorang dikatakan secara hukum bertanggungjawab untuk suatu perbuatan tertentu adalah bahwa dapat dilekatkan pada dirinya suatu sanksi dalam kasus yang berlawanan. Normalnya, dalam kasus sanksi dikenakan terhadap deliquent adalah karena perbuatannya sendiri yang membuat orang tersebut bertanggungjawab. Pertanggungjawaban dibedakan menjadi dua berdasarkan ajaran tradisional yaitu pertanggungjawaban berdasarkan kesalahan (based on fault) dan pertanggungjawaban mutlak (absolut responsibility). ${ }^{2}$
Korupsi merupakan perbuatan hukum melawan hukum yang menyangkut aspek perdata dan pidana dalam satu kesatuan, yang tidak dapat dipisahkan layaknya dua sisi mata uang. Pertanggungjawaban pemidanaan tidak hanya dilekatkan kepada pelaku korupsi, melainkan unsur keperdataan pun menjadi tanggungjawab dalam penegakan hukum terhadap extraordinarycrime ini. Tanggungjawab perdata disandangkan pada konteks kerugian materil dengan mengembalikan harta atau uang hasil tindak pidana korupsi, unsur kerugian negara merupakan pokok dari pengembalian harta tersebut. Tolak ukur utama yang harus digunakan untuk menghukum koruptor adalah keadilan dan kepentingan masyarakat, nilai materil yang dikembalikan kepada negara harus dapat mengakomodir tuntutan yang berkembang di masyarakat yang berhubungan dengan nilai-nilai dan rasa keadilan yang hidup. Lain kata setiap penegakan hukum di samping dimaksudkan untuk memperoleh kepastian hukum, ditujukan pula untuk perlindungan yang berintikan rasa keadilan masyarakat, ${ }^{3}$

1 Ishaq, Dasar-dasar Ilmu Hukum, Sinar Grafika, Jakarta, 2009, hlm. 6.

2 Jimly Asshidiqie dan M. Ali Safa'at, Teori Hans Kelsen tentang Hukum, Konstitusi Press (Konpress), Jakarta, Juli 2011, hlm. 56. Prinsip tanggungjawab atas dasar kesalahan (the based on fault, liability based on fault), yaitu tanggungjawab atas dasar kesalahan yang menyatakan seseorang dapat dimintakan pertanggungjawabannya secara hukum jika terdapat unsur kesalahan yang dilakukannya. Tanggungjawab ini diatur dalam Pasal 1365 KUHP (Kitab Undang-undang Hukum Perdata), yang di dalamnya mengandung unsur 1). Adanya perbuatan melawan hukum, 2). Adanya kesalahan. 3). Adanya kerugian yang ditimbulkan, 4). Adanya hubungan sebab akibat antara perbuatan yang satu dengan kerugian. Kesalahan ini diartikan sebagai suatu perbuatan yang memiliki unsur-unsur pertentangan dengan hukum dan bertentangan pula dengan kepatutan dan kesusilaan masyarakat. Prinsip tanggungjawab mutlak (no-fault liability, strict liability absolute, liability principle). Prinsip ini memandang pihak yang disangkakan merugikan pihak akibat perbuatannya harus membuktikan bahwa dirinya tidak memberikan kerugian sebagaimana sangkaan atas dirinya. Prinsip ini menjadi terbantahkan bila berada pada keadaan force majeure atau suatu kondisi terpaksa yang diakibatkan oleh keadaan alam dan tidak mungkin dapat dihindarkan. M. Masril, Mekanisme Penyelesaian Sengketa Konsumen terhadap Produk Cacat dalam Kaitannya dengan Tanggungjawab Produsen, Tesis Program Magister Ilmu Hukum, Sekolah Pascasarjana Universitas Sumatera Utara, 2009, Tidak dipublikasikan, hlm. 38-39.

3 Eggi Sudjana, Republik Tanpa KPK Koruptor Harus Mati, JP Books, Surabaya, 2008, hlm. 128-130. 
Pertanggungjawaban perdata diarahkan kepada perlindungan-perlindungan terhadap kepentingan-kepentingan (interests) yang berbeda-beda dalam masyarakat yang dilindungi oleh hukum dan orang harus menghormati kepentingan-kepentingan tersebut bahkan memiliki kewajiban untuk menghormati (the duty of respect) terhadap kepentingan tersebut. Konteks menghormati kepentingan tersebut maka pelanggaran terhadap kepentingan-yang dilindungi dapat dikatakan sebagai perbuatan melawan hukum. ${ }^{4}$ Paradigma corrective justice, merupakan prinsip dasar keberadaan tanggungjawab untuk memulihkan kembali keadaan semula sehingga dasar pemikirannya adalah untuk mengganti kerugian yang timbul akibat konsekuensi adanya hubungan kausalitas dari tindakan tersebut. Perbuatan melawan hukum merupakan turunan dari paradigma ini yang memiliki definisi yang jauh lebih luas karena mencakup kepada yang tertulis maupun yang tidak tertulis, seperti tata susila, kepatutan dan kehati-hatian yang seharusnya dimiliki seseorang dalam masyarakat atau terhadap benda masyarakat. ${ }^{5}$

Pertanggungjawaban pidana pada dasarrnya merupakan upaya ynag ditujukan tidak hanya untuk memberikan efek jera atau pembalasan atas suatu tindakan kejahatan, melainkan memiliki fungsi layaknya pertamggumgjawaban perdata yaitu untuk m,elindungi kepentingan masyarakat. Pembalasan terhadap tindak kejahatan tidak mempunyai nilai,tetapi hanyalah sebagai sarana untuk melindungi kepentingan masyarakat,menurut Johannes Andenaes teori ini disebut sebagaiteori perlindungan masyarakat" (the theory of social defence). Konsekuensi logisnya, penganut teori inidapat disebut golongan "Reducers" (penganut teori reduktif). Pidanabukanlah sekedar untuk melakukan pembalasan atau pengimbalan kepadaorang yang telah melakukan suatu tindak pidana, tetapi mempunyai tujuantujuantertentu yang bermanfaat ${ }^{6}$

Kedua tanggungjawab ini berkaitan dengan apa yang dikenal dengan kejahatan yang dapat meruntuhkan sendi-sendi kenegaran yaitu korupsi, pengaruh akan kejahatan ini sampai kepada penyalahahgunaan kekuasaan dan kewenangan oleh pejabat publik (negara) terhadap tindakan tersebut. Salah satu contoh akan lekatnya tindak pidana korupsi dengan kekuasaan adalah terhadap Angelina Sondakh Anggota Dewan Perwakilan Rakyat Republik Indonesia (DPR RI) masa jabatan periode 2009 - 2014, berperan untuk membahas usulan anggaran di Badan Anggaran DPR RI menyanggupi akan mengusahakan anggaran yang dialokasikan untuk proyek-proyek pada program pendidikan tinggi di Kementerian

4 Munir Fuady, Perbuatan Melawan Hukum (Pendekatan Kontemporer), Citra Aditya Bekti, Bandung, 2000, hlm. 14.

5 Anonim.

6 Ninil Eva Yustina, Perbuatan Melawan Hukum Materiil (Materiel Wederrechtelijkeheid) dalam Tindak Pidana Korupsi pada Praktik Peradilan Indonesia Pasca Putusan Mahkamah Konstitusi, Rangkuman Tesis, Magister Ilmu Hukum Universitas Merdeka, Malang, 2009, hlm. 17. 
Pendidikan Nasional Republik Indonesia (Kemendiknas) dan program pengadaan sarana dan prasarana olahraga di Kementerian Pemuda dan Olahraga Republik Indonesia (Kemenpora) dapat disesuaikan dengan permintaan Permai Grup karena proyek tersebut dapat dikerjakan oleh Permai Grup ataupun pihak lain yang telah dikoordinasikan oleh Permai Grup. ${ }^{7}$

Korupsi dikategorikan sebagai perbuatan melawan hukum karena sifatnya tidak hanay melanggar undang-undang, melainkan melanggar terhadap hak orang lain terutama pelanggaran terhadap kepentingan masyarakat. Perbuatan melawan hukum (onrechtmatige daad atau tort law) mengalami perkembangan dalam beberapa dekade ini. Seratus tahun lalu bidang kajian ini sangat kecil, dan pada dasarnya hanya mencakup dua perbuatan: pelanggaran aturan perundangundangan dan pelanggaran langsung dari hak dari orang/pihak lain. Abad ke duapuluh justru menunjukkan perkembangan pesat hukum tidak tertulis. Suatu tindakan (mencakup berbuat atau tidak berbuat) sejak itu juga menjadi melawan hukum dan atas dasar ini dapat memunculkan kewajiban pihak yang bertindak memberi ganti rugi bilamana bertentangan dengan kecermatan/kehatihatian yang juga dituntut di dalam lalu lintas pergaulan masyarakat terhadap pihak atau kebendaan lain. ${ }^{8}$

Rosa Agustina menjelaskan lebih lanjut bahwa suatu perbuatan dapat dikategorikan tidak hanya terpenuhinya unsur-unsur perbuatan melawan hukum yaitu: (a) perbuatan tersebut dikategorikan sebagai perbuatan melawan hukum, (b) adanya kesalahan pada pelaku (schuld), (c) harus ada kerugian, dan (d) ada hubungan kausa antara perbuatan dan kerugian. Unsur lain yang harus terpenuhi adalah bahwa melawan hukum hukum itu sendiri memerlukan empat syarat, yakni (1) bertentangan dengan kewajiban hukum pelaku, ${ }^{9}$ (2) bertentangan dengan hak subjektif orang lain, (3) bertentangan dengan kesusilaan, ${ }^{10}(4)$ bertentangan dengan

7 Anonim.

8 Rosa Agustina dkk, Pengantar Penulis, dalam Hukum Perikatan (Law of Obligations), diterbitkan oleh Pustaka Larasan Denpasar atas kerjasama antara Universitas Indonesia, Universitas Leiden dan Universitas Groningen, 2012, hlm. vii.

9 Suatu perbuatan termasuk ke dalam kategori perbuatan melawan hukum jika perbuatan tersebut bertentangan dengan kewajiban hukum dari pelakunya. Istilah kewajiban hukum (rechtsplicht) ini, yang dimaksudkan adalah bahwa suatu kewajiban yang diberikan oleh hukum terhadap seseorang, baik hukum tertulis maupun hukum tidak tertulis. Jadi, bukan hanya bertentangan dengan hukum tertulis (wettelijk plicht), melainkan juga bertentangan dengan hak orang lain menurut undang-undang (wettelijk recht). Karena itu pula, istilah yang dipakai untuk perbuatan melawan hukum adalah onrechtmatige daad, bukan onwetmatige daad. Munir Fuady, Perbuatan Melawan Hukum Pendekatan Kontemporer, Citra Aditya Bakti, Bandung, 2005, hlm. 8.

10 Kesusilaan berarti perihal susila, yang berkaitan dengan adab dan sopan santun. Susila bermakna baik budi bahasanya, beradab, sopan, tertib, adat istiadat yang baik, sopan santun, kesopanan, keadaban. Kesusilaan yang baik adalah yang dapat dinyatakan sebagai norma-norma moral atau yang dalam pergaulan masyarakat telah diterima sebagai norma-norma hukum. J. Satrio, Hukum Perikatan (Perikatan yang Lahir dari Undang-undang), Citra Aditya Bakti, Bandung, 1993, hlm. 186. 
kepatutan, ketelitian dan kehati-hatian. ${ }^{11}$

Pertanggungjawaban menjadi penting dalam penegakan hukum terutama yang berkaitan dengan tindak pidana korupsi, pentingya hal ini tampak dalam bentuk kerugian negara yang berujung pada tingkat kesejahteraan masyarakat, korupsi berdampak buruk terhadap tingkat kesejahteraan masyarakat terlihat dari hasil analisis kebijakan fiskal melalui instrumen penerimaan dan pengeluaran pemerintah terhadap tingkat kesejahteraan masyarakat. Pengaruh pengeluaran pemerintah terhadap kesejahteraan masyarakat di negara yang tingkat korupsinya tinggi, memiliki nilai estimasi (koefisien) tidak signifikan, jika dibandingkan dengan pengaruh pengeluaran pemerintah terhadap kesejahteraan masyarakat di negara yang tingkat korupsinya rendah. Negara yang tingkat korupsinya tinggi, memiliki tingkat kesejahteraan yang lebih rendah dibandingkan dengan negara yang tingkat korupsinya rendah walaupun nilainya tidak signifikan. ${ }^{12}$ Bank dunia mengungkapkan bahwa korupsi menghambat efisiensi ekonomi, mengalihkan sumbersumer dari orang miskin kepada orang kaya, mengdistorsi pengeluaran-pengeluaran publik dan membuat jera investor-investor asing. Korupsi juga mengikis perwakilan programprogram pembangunan dan mengurangi masalah-masalah kemanusiaan. ${ }^{13}$

Tanggungjawab dalam konteks perbuatan melawan hukum bukan hanya atau tidak hanya diartikan sebagai sebuah bentuk ganti rugi yang berkonotasi dengan kepentingan

11 Rosa Agustina, Perbuatan Melawan Hukum, Disertasi Fakultas Hukum Universitas Indonesia, 2003, hlm. 51-54. Perbuatan yang bertentangan dengan kehati-hatian atau keharusan dalam pergaulan masyarakat yang baik ini juga dianggap sebagai suatu perbuatan melawan hukum. Jadi, jika seseorang melakukan tindakan yang merugikan orang lain, tidak secara melanggar pasal-pasal dari hukum tertulis, mungkin masih dapat dijerat dengan perbuatan melawan hukum, karena tindakannya tersebut bertentangan dengan prinsip kehatihatian atau keharusan dalam pergaulan masyarakat. Keharusan dalam masyarakat tersebut tentunya tidak tertulis, tetapi diakui oleh masyarakat yang bersangkutan. Munir Fuady, Perbuatan Melawan Hukum Pendekatan Kontemporer, Citra Aditya Bakti, Bandung, 2005, hlm. 9.

12 Henry P. Panggabean, Penegakan Hukum Tindak Pidana Korupsi Mendukung Pembangunan Hukum Berbasis Hak Asasi Manusia, Jurnal Legislasi Indonesia Volume 10 No. 02, Juni 2013, hlm. 164. Penelitian ini diarahkan pada dampak korupsi negara-negara dengan mayoritas muslim (negara muslim), terhadap kesejahteraan mayrakat. Sampel negara muslim yang diteliti berjumlah 31 negara, yaitu Bangladesh, Turkmenistan, Cote d'Ivoire, Pakistan, Tajikistan, Azerbaijan, Indonesia, Uzbekistan, Kyrgyz Republic, Albania, Sierra Leone, Togo, Uganda, Kazakhstan, Benin, Iran, Mali, Algeria, Lebanon, Morocco, Maldives, Burkina Faso, Egypt, Turkey, Kuwait, Tunisia, Malaysia, Jordan, Bahrain, Oman, dan Brunei Darussalam. Untuk mengetahui dampak korupsi terhadap tingkat kesejahteraan masyarakat menggunakan dua cara. Pertama, dengan melihat pengaruh kebijakan fiskal (penerimaan dan pengeluaran pemerintah) terhadap tingkat kesejahteraan masyarakat di dua kelompok negara, yaitu kelompok negara yang tingkat korupsinya tinggi (IPK < 3) dan kelompok negara yang tingkat korupsinya rendah (IPK \&\#8805; 3). Kedua, dengan menganalisa tingkat kesejahteraan di dua kelompok negara tersebut. Data yang digunakan dalam penelitian ini adalah data tahun terakhir, yaitu tahun 2006. Tingkat korupsi suatu negara diukur dengan Indeks Persepsi Korupsi (IPK) yang dikeluarkan oleh lembaga Transparansi Internasional setiap tahunnya, tingkat kesejahteraan masyarakat diukur dengan Indeks Pembangunan Manusia (IPM) atau Human Develompent Index (HDI) yang dikeluarkan oleh UNDP, dan anggaran penerimaan dan belanja pemerintah diukur dari persen PDB dari masing-masing negara. Data tersebut diperoleh dari beberapa hasil publikasi BPS, IDB dan Bank Dunia. Proses estimasi didasarkan pada analisis model persamaan struktural (Structural Equation Modelling)

13 Evi Hartanti, Tindak Pidana Korupsi, Sinar Grafika, Jakarta, 2009, hlm. 25. 
pribadi, melainkan harus dimaknai sebagai sebuah konsekuensi hukum dalam penegakan hukum yang berorientasi pada kesejahteraan masyarakat.Kondisi ini menjadi penting untuk kumandangkan bahkan diakomodir karena sifatnya tidak lagi sebagai local ordinary crime, tetapi cenderung dilihat sebagai suatu fenomena kejahatan transnasional yang dapat mempengaruhi kehidupan masyarakat internasional. ${ }^{14}$

Pertanggungjawaban dalam tindak pidana korupsi bukanlah suatu hal yang asing dalam penegakan hukum di Indonesia, contoh nyata adalah pendaftaran gugatan perdata mantan Presiden Soeharto ke Paniteraan Pengadilan Negeri Jakarta Selatan pada tanggal 9 Juli 2007 dengan daftar perkara Nomor 904/Pdt.G/2007/ PN.Jak.Sel. Pendaftaran gugatan ini dilakukan oleh Kejaksaan Agung dengan maksud membuka kembaliupaya pengembalian kerugian keuangan negara terhadap harta kekayaan mantan Presiden Soeharto. Ketua Tim Jaksa Pengacara Negara (JPN), DachamerMunthe mengatakan, "Kualifikasi gugatan perdata yang didaftarkan Kejaksaan adalah perbuatan melawan hukum karena pengumpulan dana yang disalurkan kepada Yayasan Supersemar tidak sesuai dengan peruntukan".Kejaksaan mengajukan gugatan ganti rugi materil sebesar Rp.1,5 triliun dan immateril Rp.10 triliun. ${ }^{15}$

Gugatan perdata terhadap Mantan Presiden ke-2 RI tersebut hanya terfokus pada pengembalian dana kepada negara saja, hal ini sesuai dengan asas dan tujuan di dalam Stolen Asset Recovery Initiative sebagai dasar pokok dalam pengembalian kerugian keuangan negara. ${ }^{12}$ Strategi pencegahan korupsi harus dilihat sebagai upaya, strategis di samping upaya pemberantasan (represif). Dan yang lebih penting lagi adalah strategi pengembalian asset (asset recovery) hasil korupsi. ${ }^{16}$ Jalur keperdataan dalam perampasan aset negara, dibandingkan jalur pidana relatif lebih mudah karena dalam hal pembuktian, pemerintah cukup mempunyai bukti awal bahwa aset yang akan diambil adalah hasil, atau berhubungan dengan tindak pidana. ${ }^{17}$

14 Anonim.

15 Hukim Online, "Yayasan Supersemar Resmi Digugat", "Perburuan harta mantan Presiden Soeharto kembali dimulai, Mungkinkah berhasil?", http://www.hukumonline.com/detail.asp?id=17123\&cl=Berita, diakses 14 Januari 2010 pukul 10.00 WIB.

Gagasan untuk menggugat Soeharto secara perdata, pertama kali dilontarkan oleh Baharudin Lopa yang menggantikan Marzuki Darusman. Setelah itu, penyidikan terhadap Soeharto menggantung karena sakit bahkan H.M. Soeharto telah meninggal dunia. Akhirnya dikeluarkan Surat Keputusan Penghentian Penuntutan Perkara (SKP3) oleh Jaksa Agung yang dijabat Abdul Rahman Saleh pada 2004. Bismar Nasution, "Stolen Asset Recavery Initiative dari Perspektif Hukum Ekonomi di Indonesia", Makalah disajikan dalam Seminar Pengkajian Hukum Nasional 2007 (SPHN 2007), Jakarta, 28 Nopember 2007, hlm. 11.

16 I. Gusti Ketut Ariawan, "Stolen Asset Recovery Initiative, Suatu Harapan dalam Pengembalian Aset Negara”, Jurnal Kertha Patrika, Volume 33 No. 01, Bali, Januari 2008, hlm. 6.

17 Irdanul Achyar, Analisis Pengimplementasian Rezim Civil Forfeiture dalam Pemberantasan Money Laundering, Skripsi Fakultas Hukum Universitas Sumatera Utara, Medan, 2010, hlm. 6. Implementasinya adalah apa yang disebut civil forfeiture. Dalam masalah pembuktian, pemerintah cukup menghitung berapa pendapatan yang layak bagi pelaku, kemudian membandingkan dengan aset yang dimiliki. Jika aset yang dimiliki melebihi jumlah pendapatannya, maka pelaku berkewajiban membuktikan bahwa aset tersebut diperoleh secara legal. 
Berdasarkan uraian di atas, permasalahan yang diangkat adalah:

1. Apakah perbuatan melawan hukum dapat menjadi dasar untuk meminta tanggungjawab terhadap suatu tindak pidana korupsi

2. Bagaimanakah perbuatan melawan hukum menjadi dasar untuk meminta tanggungjawab dalam suatu tindak pidana korupsi?.

Peter Mahmud Marzuki penelitian hukum adalah suatu proses untuk menemukan aturan hukum, prinsip-prinsip hukum maupun doktrin-doktrin hukum guna menjawab isu hukum yang dihadapi. ${ }^{18}$ Penelitian ini mengunakan metode penelitian yuridis normatif dengan pendekatan konseptual yang ditujukan untuk menganalisis bahan-bahan hukum yang mengacu kepada norma-norma hukum, baik itu dalam peraturan perundangundangan maupun putusan pengadilan, ${ }^{19}$ terutama yang berkaitan dengan tindak pidana korupsi.

\section{Pembahasan}

\section{A. Tanggungjawab Perdata}

Tanggung jawab perdata dalam terminologi perbuatan melawan hukum berasal dari prinsip atas dasar kesalahan yang dilekatkan pada suatu perbuatan sebagai suatu kesalahan apabila terdapat pelaku yang dapat dimintakan suatu pertanggungjawaban secara hukum atas perbuatannya tersebut. Indonesia menganut prinsip ini dan termaktub dalam Kitab Undang-Undang Hukum Perdata (KUHP), tentang perbuatan melawan hukum (onrechtmatigedaad). ${ }^{20}$ Kesalahan diartikan sebagai suatu perbuatan yang dilakukan baik itu karena kesengajaan maupun karena kelalaian, sehingga tanggungjawab akan kesalahan tersebut tidak hanya secara moral (moral liability) melainkan secara hukum pula (legal liability). ${ }^{21}$ Perbuatan melawan hukum karena didasarkan pertanggungjawaban untuk terpenuhinya salah satu unsurnya yang merupakan unsur kesalahan, dalam hukum modern, pertanggungjawaban terhadap

18 Peter Mahmud Marzuki, Penelitian Hukum, Kencana, Jakarta, 2009, hlm. 35.

19 Ridwan Khairandy, Landasan Filosofis Kekuatan Mengikatnya Kontrak, Jurnal Hukum, Edisi khusus Volume 18 oktober 2011, hlm. 39.

20 Endang Saefullah Wiradipraja, Tanggungjawab Pengangkut dalam Hukum Udara, Balai Pustaka, Jakarta, 1996, hlm. 9. Tanggung jawab dengan unsur kesalahan (kesengajaan dan kelalaian) sebagaimanapun terdapat dalam Pasal 1365 KUHPerdata, yaitu: "Tiap-tiap perbuatan melanggar hukum, yang membawa kerugian kepada seorang lain, mewajibkan orang yang karena salahnya menerbitkan kerugian itu, mengganti kerugian tersebut". Tanggung jawab dengan unsur kesalahan khususnya kelalaian sebagaimana terdapat dalam Pasal 1366 KUHPerdata yaitu: "Setiap orang bertanggungjawab tidak saja untuk kerugian yang disebabkan perbuatannya, tetapi juga untuk kerugian yang disebabkan kelalaian atau kurang hati-hatinya.

21 Endang Saefullah Wiradipradja, Hukum Transportasi Udara: dari Warsawa 1929 ke Monteral 1999, Kiblat Utama, Bandung, 2008, hlm. 172. 
aktivitas yang disinyalir termasuk akitivitas berbahaya ditentukan sesuai dengan kerangka umum dari sistem pertanggungjawaban yang berdasarkan adanya delik. Hal ini berarti terdapat suatu keharusan untuk menunjukkan benar-benar terdapatnya unsur kesalahan dalam aktivitas tersebut. ${ }^{22}$

Tanggung jawab hukum dalam hukum perdata berupa tanggung jawab seseorang terhadap perbuatan yang melawan hukum. Perbuatan melawan hukum memiliki ruang lingkup yang lebih luas dibandingkan dengan perbuatan pidana. Perbuatan melawan hukum tidak hanya mencakup perbuatan yang bertentangan dengan undang-undang pidana saja, akan tetapi jika perbuatan tersebut bertentangan dengan undang-undang lainnya dan bahkan dengan ketentuan-ketentuan hukum yang tidak tertulis. Ketentuan perundang-undangan dari perbuatan melawan hukum bertujuan untuk melindungi dan memberikan ganti rugi kepada pihak yang dirugikan. ${ }^{23}$

Ruang lingkup yang luas terhadap tanggungjawab perdata memberikan gambaran akan fleksibelitas prinsip ini yang dapat diterapkan pada setiap peristiwa hukum, terutama yang berkaitan dengan wilayah keperdataan. Cakupannya dapat dikenakan terhadap manusia sebagai naturelijk persoon maupun terhadap badan hukum atau rechtpersoon. Konsekeunsi yang lahir dari perluasaan ini setiap subjek hukum dapat dimintai pertanggungjawaban atas setiap kesalahan yang dilakukannya dengan catatan adanya kerugian yang timbul akibat kesalahan tersebut.

Prinsip ini dikenal dengan teori Corrective Justice, yang mengajarkan bahwa setiap orang harus melindungi hak-haknya dan harus dipulihkan keadaannya agar ada keseimbangan antara keadilan dan kepastian hukumyang merupakan tujuan hukum. ${ }^{24}$ Perluasan itu muncul karena adanya tiga Arrest Hoge Raad yang memiliki nilai historis yangmenggambarkan terhadap pemahaman istilah "melawan hukum". Arrest pertama adalah Arrest Hoge Raad 6 Januari 1905 dalam perkara Singer Naaimachine.Arrest kedua adalah Arrest Hoge Raad 10 Juni 1910 dalam perkara kasusZutphenese Juffrouw. Arrest ketiga adalah Hoge Raad 31 Januari 1919 dalamperkara Lindenbaum vs. Cohen. ${ }^{25}$

Arrest Hoge Raad 6 Januari 1905 dalam perkara Singer Naaimachine. Perkara bermula dari seorang pedagang menjual mesin jahit mere "Singer" yang telah disempurnakan. Padahal mesin itu sama sekali bukan produk dari Singer. Kata-kata "Singer" ditulis dengan huruf-huruf yang besar, sedang kata-kata yang

22 Loura Hardjaloka, Ketetapan Hakim dalam Penerapan Precautionary Principle Sebagai "Ius Cogen" dalam Kasus Gunung Mandalawangi, Kajian Putusan Nomor 1794K/Pdt/2004, Jurnal Yudisial, Volume 5, No. 2, Agustus 2012, hlm. 137.

23 Komariah, Hukum Perdata, Universitas Muhammadiyah Malang, Malang, 2001, hlm. 12.

24 Ahmad Sudiro, Konsep Keadilan John Rawls, Jurnal Legislasi Indonesia, Volume 19 No. 3, Juli 2012, hlm. 446.

25 Kiki Nitalia Hasibuan, Perbuatan Melawan Hukum dalam Kasus Mis-Selling, Skripsi pada Fakultas Hukum Universitas Indonesia, Jakarta, 2011, hlm. 43. 
lain ditulis kecil-kecil sehingga sepintas yang terbaca adalah"Singer" saja. Ketika pedagang itu digugat di muka pengadilan berdasarkan Pasal 1365 KUHPerdata (1401 B.W Belanda), Hoge Raad menolaknya karena pada waktu itu tidak ada peraturan perundang-undangan yang melindungi hak terhadap merek dagang. ${ }^{26}$

Arrest kedua Hoge Raad berpendapat sama dalam kasus Zutphenese Juffrouw. Perkara yang diputuskan tanggal 10 Juni 1910 itu bermula dari sebuah rumah bertingkat di kota Zutphen, pipa air yang berada di gudang lantai bawah mengalami kerusakan karena suhu yang sangat dingin. Kerusakan pipa air tersebut mengakibatkan rusaknya barang-barang yang tersimpan dalam gudang, sementara kran induk berada di rumah tingkat atas. Pemilik gudang mengetuk pintu kamar rumah lantai atas namun penghuninya tidak bersedia untuk memenuhi permintaannya untuk menutup kran induk tersebut. Akibat tidak dipenuhinya permintaan pemilik gedung timbul kerusakan besar pada barang yang tersimpan dalam gudang akibat tergenang air. Perusahaan asuransi telah membayar ganti kerugian atas rusaknya barang-barang tersebut dan selanjutnya menggugat penghuni rumah tingkat atas di muka Pengadilan atas dasar perbuatan melawan hukum. Hoge Raad memenangkan tergugat dengan alasan, bahwa tidak terdapat suatu ketentuan Undangundang yang mewajibkan penghuni tingkat atas tersebut untuk mematikan kran induk guna kepentingan pihak ketiga. Hoge Raad di Belanda pada saat itu memandang perbuatan melawan hukum secara legistis. ${ }^{27}$

Pandangan legistis itu kemudian berubah pada tahun 1919 dengan putusan Hoge Raad 31 Januari 1919 dalam perkara Lindenbaum vs. Cohen yang dikenal sebagai Drukkers Arrest. Dalam perkara ini, Cohen seorang pengusaha percetakan telah membujuk karyawan percetakan Lindenbaum untuk memberikan copy-copy pesanan dari para pelanggannya. Cohen memanfaatkan informasi ini sehingga Lindenbaum mengalami kerugian karena para pelanggannyaberalih ke perusahaan Cohen. Tindakan yang dilakukan oleh Lindenbaum adalah dengan menggugat Cohen untuk membayar ganti kerugian kepadanya. Gugatan tersebut dikabulkan oleh Pengadilan Negeri (Rechtbank), sedangkan Pengadilan Tinggi (Hof) membatalkan Putusan Pengadilan Negeri. ${ }^{28}$

Hoge Raad membatalkan keputusan Hof tersebut atas dasar pertimbangan, bahwa dalam keputusan Pengadilan Tinggi makna tentang perbuatan melawan hukum

26 Ibid., hlm. 43. Dalam pertimbangannya Hoge Raad antara lain mengatakan, bahwa perbuatan pedagang itu bukanlah merupakan tindakan melawan hukum karena tidak setiap tindakan dalam dunia usaha, yang bertentangan dengan tata karma dalam masyarakat dianggap sebagai tindakan melawan hukum

27 Rachmat Setiawan, Tinjauan Elementer Perbuatan Melawan Hukum, Binacipta, Bandung, 1991, hlm. 9.

28 Dengan pertimbangan, bahwa sekalipun karyawan tersebut melakukan perbuatan yang bertentangan dengan undang-undang, yakni telah melanggar suatu kewajiban hukum, namun tidak berlaku bagi Cohen karena Undang-undang tidak melarang dengan tegas bahwa mencuri informasi adalah melawan hukum. 
(onrechtmatigedaad) dipandang secara sempit sehingga yang termasuk di dalamnya hanyalah perbuatan-perbuatan yang secara langsung dilarang oleh undang-undang. ${ }^{29}$ Arrest Hoge Raad memberikan definisi baru yang berkaitan dengan perbuatan melawan hukum, yang sedikitnya mempengaruhi setiap aturan dan hukum yang berkembang di Indonesia pada dewasa ini. Pernyataan tersebut menyatakan "perbuatan melawan hukum adalah bukan hanya perbuatan yang bertentangan dengan undang-undang (wet), melainkan juga perbuatan yang dipandang dari sudut pergaulan masyarakat tidak patut. ${ }^{30}$

Perubahan cara pandang perbuatan melawan hukum di Indonesia akibat pengaruh dari Arrrest Hoge Raad di Belanda mengarahkan suatu tindakan dapat dikategorikan sebagai suatu kesalahan atau kelalaian ditujukan tidak hanya dalam aturan yang bersifat formalistis yang ditujukan dengan suatu aturan yang tertulis, melainkan diarahkan pula kepada suatu aturan tidak tertulis yang dapat mempengaruhi konteks suatu perbuatan tersebut dapat digolongan sebagai suatu kesalahan atau kelalaian.

\section{B. Tanggungjawab Pidana}

Secara etimologis tindak pidana, selalu diawali dengan kata "barangsiapa", yang memiliki konotasi terhadap pelaku tindak pidana yang melakukan kesalahan. Kesalahan dapat dilakukan atas dasar kesengajaan dan karena kelalaiannya. Kesengajaan merupakan perbuatan manusia dalam kesalahan, terdapat dua sifat dalam hal melaksanakan kesalahan tersebut, yaitu kesengajaan (dolus) dan kelalaian (culpa). Perbuatan dilakukan dengan sengaja adalah perbuatan yang dikehendaki dan dilakukan dengan penuh kesadaran. Tanggung jawab pidana bagi seseorang yang melakukan perbuatan yang dilarang dan kepadanya dikenakan sanksi berupa pidana adalah apabila pelaku melakukan kesalahan baik yang dilakukan atas dasar kesengajaan atau atas dasar kelalaiannya, yang berarti bahwa tanggung jawab pidana dari pelaku tindak pidana adalah karena telah dengan sengaja atau karena kelalaiannya mengakibatkan terjadi perbuatan melanggar hukum. ${ }^{31}$

Pertanggungjawaban pidana merupaka konsekuensi yang diterima oleh seseorang karena telah melakukan perbuatan yang melanggar undang-undang pidana atau perbuatan yang sengaja dilakukan dengan melawan hukum, oleh karena itu pelaku harus menerima pidana (hukuman) dengan bentuk pertanggung jawaban atas perbuatannya tersebut. Pertanggung jawaban pidana terhadap pelaku disini adalah bagi mereka atau pelaku yang sudah berusia dewasa dan dalam

29 Rosa Agustina, Perbuatan Melawan Hukum, dalam Hukum Perikatan (Law of Obligations), Op.cit., hlm.7.

30 R. Achmad S. Soemadipraja, Hukum Pidana dalam Yurisprudensi, Armico, Bandung, 1990, hlm. 67.

31 Widyawati Budiningsih, Jefri Hardi, Pertanggungjawaban Pidana Penyelenggara Jalan terhadap Korban Akibat Kerusakan Jalan, Jurnal Hukum, Volume XIX, No. 19, Oktober 2010, hlm. 36. Bentuk kesengajaan menurut Moeljatno terdiri dari tiga corak, yaitu: 1) Kesengajaan dengan maksud (dolus derictus); 2) Kesengajaan sebagai kepastian, keharusan, dan 3) Kesengajaan sebagai kemungkinan (dolus eventualis). 
keadaan sehat jasmani dan rohaninya, hanya karena itulah pelaku mampu bertanggung jawabkan atas semua perbuatannya. ${ }^{32}$

Pentingnya kedewasaan dan sehat secara jasmani dan rohani dalam tanggungjawab pidana terhadap tindak pidana bukan tanpa alasan. Argumentasi akan pentinganya tiga hal tersebut adalah untuk mementukan layak atau tidaknya seseorang untuk diberikan dan dijatuhkan sanksi terhadap perbuatannya tersebut, karena akan hilang esensi dari sanksi yaitu sebagai sarana untuk memberikan efek jera atau pembelajaran bila pelaku suatu tindak pidana tidak memiliki ketiga unsur tersebut. Penguatan argumentasi ini dikemukakan oleh Moeljatno bahwa pelaku tindak pidana dapat dikenakan sanksi bila memiliki unsur-unsur sebagai berikut:

1. Kemampuan membeda-bedakan antara perbuatan yang baik dan buruk, sesuai dengan hukum dan yang melawan hukum. Dalam hal ini merupakan faktor akal (intelectual factor) yaitu dapat membeda-bedakan antara perbuatan yang diperbolehkan dan yang tidak.

2. Kemampuan untuk menentukan kehendaknya menurut keinsyafan tentang baik dan buruknya perbuatan tadi. Dalam hal ini merupakan faktor perasaan atau kehendak (volitional factor) yaitu dapat menyesuaikan tingkah lakunya dengan keinsyafan atas mana yang diperbolehkan dan mana yang tidak. ${ }^{33}$

Kemampuan bertanggung jawab psikis menurut Hazewinkel-Suringa bukanlah syarat umum dapatnya dipidana (strafbaarheid). Kemampuan bertanggung jawab bukanlah pengertian yang statis, harus juga dilihat keadaan-keadaan sosial dan sifat delik itu sendiri apakah seseorang tidak dapat dipertanggungjawabkan. Dapat dipertanggungjawabkan merupakan suatu variasi khusus dari kesalahan. Lebih lanjut menurut Hazewinkel-Suringa, jika tidak dapat dipertanggungjawabkan maka tidak ada kesalahan. ${ }^{34}$ Asas utama dalam pertanggungjawaban pidana adalah harus adanya kesalahan pada pelaku (Geen straf zonder schuld; keine strafe ohne schuld). Ajaran yang banyak dianut sekarang ini memisahkan antara perbuatan yang melawan hukum (menurut hukum pidana) dengan pertanggungjawaban pidana menurut hukum pidana. $^{35}$

Unsurfilosofis, sosiologis dan kriminologis yang menjadi latar belakang pentingnya lainnya terhadap suatu pertanggungjawaban pidana, karena pemidanaan pada dasarnya merupakan gambaran dari sitem moral, nilai kemanusiaan dan pandangan filosofis suatu masyarakat manusia pada suatu zaman.

32 Moch Juli Pudjiono, Sigit Sapto Nugroho, Pertanggung Jawaban Pidana Pelaku Tindak Pidana Perdagangan Orang (Trafficking), Jurnal Sosial, Volume 15 No. 1, Maret 2014, hlm. 46.

33 Ibid., hlm. 47.

34 Auliah Andika, Pertanggungawaban Pidana Korporasi pada Tindak Pidana Pencucian Uang, Tesis pada Fakultas Hukum Universitas Indonesia, Jakarta, 2010, Tidak dipublikasikan, hlm. 79.

35 Orpa Ganefo Manuain, Pertanggungjawaban Pidana Korporasi dalam Tindak Pidana Korupsi, Tesis pada Fakultas Hukum Universitas Diponegoro, Semarang, 2005, Tidak dipublikasikan, hlm. 10. 
Penyelesaian konflik (conflict resolution), mempengaruhi para pelanggar dan orangorang lain ke arah perbuatan yang lebih sesuai dengan hukum (influencing offenders and possibly other than offenders toward more or less law-conforming behavior), merupakan puncak dari pengaruh ketiga usnur tersebut. ${ }^{36}$

Tanggungjawab pidana tidak hanya berkaitan dengan bagaimana seseorang melakukan perbuatan yang dilarang oleh undang-undang, melainkan harus dimaknai bahwa pertanggungjawaban dalam ruang lingkup pidana dipengaruhi pula oleh keadaan dan kondisi pelaku secara mentalitas, yang dapat mempengaruhi sanksi pidana. Tentu pengaruh psikis pelaku menjadi bagian pertimbangan tersebur dengan memperhatikan unsur filosofis, sosiologis dan kriminologis dari tindak pidana tersebut. Filosofis mempengaruhi esensi dari penjatuhan sanksi, sosisologis mempengaruhi penjatuhan sanksi terhadap keadaan dan situasi masyarakat terhadap tindakan pelaku, serta kriminologis berkaitan pengaruh yang akan muncul berkaitan penjatuhan sanksi bagi pelaku.

\section{Tanggungjawab Administrasi}

Tanggungjawab Administrasi (administrative responsibility) merupakan bagian utama dari penegakan etika birokrasi. Plumlee, tanggungjawab administrasi melibatkan dua hal yaitu perilaku administrator dan harapan dari masyarakat, lebih jauh tuntutan terhadap tanggyungjwab administrasi tidak hanya disandarkan kepada kepatuhan dan wewenang dan kekuasaan, melainkan ditujukan untuk merefleksikan kewajiban yang terdapat dalam kewenangan tersebut untuk menghasilkan tindakan yang bertannggungjawab. Responsibilitas memiliki peran aktif bila peraturan, kekuasaan/kewenangan bersatu dengan pengalaman untuk menentukan tindakan yang tepat. ${ }^{37}$ Kewenangan dan kekuasaan merupakan bagian terpenting dari tanggungjawab dalam ruang lingkup administrsi, kedua kata tersebut menunjukkan pihak yang memiliki kemampuan untuk melaksanakan setiap kebijakan, serta terhadap siapa akibat yang muncul dari kebijakan itu dilekatkan. Kewenangan/kekuasaan itu dapat dirinci sebagai berikut:

1. Kewenangan dari Atribusi yaitu, pemberian wewenang pemerintah berdasarkan ketentuan peraturan perundang-undangan yang dibuat oleh orginal Legislator yaitu MPR sebagai pembentuk konstitusi dan presiden bersama-sama pemerintah yang melahirkan Undang-undang serta DPRD bersama-sama pemerintah daerah yang melahirkan peraturan daerah seperti Gubernur yang diberikan wewenang oleh uu tentang Pemilu anggota DPR, DPRD

36 Septa Candra, Restorative Justice: Suatu Tinjauan terhadap Pembaharuan Hukum Pidana di Indonesia, Jurnal Rechtvinding, Volume 2 No. 2, Agustus 2013, hlm. 267-268.

37 Falakhul Firda, Administrative Responsibility Studi Deskriptif tentang Perilaku Kerja Pegawai pada Pelayanan Publik dalam Perspektif Administrative Responsibility di Dinas Kependudukan dan Catatan Sipil Kota Surabaya, Jurnal Kebijakan dan Manajemen Publik, Volume 1 No. 1, Januari 2013, hlm. 39. 
dan DPD untuk meresmikan keanggotaan DPRD.

2. Kewenangan dari Delegasi yaitu, pemberian wewenang pemerintah berdasarkan pendelegasian dari badan atau jabatan TUN yang telah memperoleh kewenangan secara atribusi yang bertindak sebagai delegated legislator, seperti Presiden yang diberikan wewenang untuk menerbitkan Peraturan Pemerintah kemudian melimpahkan wewenangnya kepada Badan atau jabatan tertentu dalarn hal ini Badan atau jabatan TIJN yang mendapat limpahan kewenangan tersebut bertanggung jawab penuh terhadap perbuatannya, sehingga apabila terjadi perbuatan melawan hukum baik karena sengaja maupun karena kelalaian maka dialah yang dapat digugat untuk mempertanggungjawabkannya.

3. Kewenangan dari Mandat yaitu, pemberian wewenang pemerintah berdasarkan hubungan intern seperti Menteri menugaskan Dirjen atau Irjennya untuk atas nama Menteri melakukan tindakan hukum mengeluarkan keputusan TUN tertentu. Dalam hal ini tidak terjadi perubahan apa-apa mengenai kewenangan, wewenang tetap ada pada pemberi mandat, sehingga apabila terjadi kesalahan maka yang bertangung jawab adalah pemberi mandat (mandans) sedangkan penerima mandat (mandataris) tidak dapat dikenai pertanggungan jawab karena dia hanya melaksanakan tugas saja tanpa ada pelimpahan wewenang. ${ }^{38}$

Wewenang merupakan bagian yang sangat penting dan bagian awal hukum administrasi, karena pemerintahan (administrasi) baru dapat menjalankan fungsinya atas dasar wewenang yang di perolehnya, artinya keabsahan tindak pemerintahan atas dasar wewenang yang diatur dalam peraturan perundang undangan (legalitiet beginselen). S.F. Marbun menerangkan bahwa wewenang mengandung arti kemampuan untuk melakukan suatu tindakan hukum publik, atau secara yuridis adalah kemampuan bertindak yang di berikan oleh undang undang yang berlaku untuk melakukan hubungan hubungan hukum. ${ }^{39}$ Wewenang merupakan ruang lingkup tindakan hukum publik, lingkup wewenang pemerintah, tidak hanya meliputi wewenang membuat keputusan pemerintah (besluit), tetapi meliputi wewenang dalam rangka pelaksanaan tugas, dan pembentukan wewenang serta distribusi

38 Ujang Abdullah, Perbuatan Melawan Hukum oleh Penguasa, Materi Bimbingan Teknis Peradilan Tata Usaha Negara Pemerintah Propinsi Lampung, 13-14 Juli 2005.

39 Ali Rahman, Tinjauan Hukum Administrasi Negara tentang Kewenangan Wakil Menteri di Indonesia, Skripsi pada Fakultas Hukum Universitas Hasanuddin, Makasar, 2013, Tidak dipublikasikan, hlm. 15. Bagir Manan, di dalam bahasa hukum wewenang tidak sama dengan kekuasaan (macht). Kekuasaan hanya menggambarkan hak untuk berbuat atau tidak berbuat, sedangkan wewenang sekaligus berarti hak dan kewajiban. Hak berisi kebebasan untuk melakukan atau tidak melakukan tindakan tertentu atau menuntut pihak lain untuk melakukan hal tertentu, sedangkan kewajiban memuat keharusan untuk melakukan atau tidak melakukan tindakan tertentu. Romi Librayanto, Trias Politica dalam Struktur Ketatanegaraan Indonesia, PuKAP, Makassar, 2008, hlm. 63. 
wewenang utamanya ditetapkan dalam dapat merugikan masyarakat atau dalam kasus undang-undang dasar. ${ }^{40}$

Perbuatan atau tindakan negara atau pemerintah tidak boleh melampaui atau melanggar hak asasi, tidak boleh menyebabkan seseorang atau sekelompok orang tidak mendapat perlindungan hukum sebagaimana mestinya, tidak boleh membedabedakan orang karena alasan-alasan yang tidak sah dan semua perbuatan atau tindakan-tindakan pemerintah harus berdasarkan pada ketentuan hukum yang berlaku. Konsep kerakyatan tidak dapat dipisahkan dari konsep negara hukum. Begitu pula sebaliknya sehingga suatu negara semacam ini disebut "negara hukum demokratis". ${ }^{41}$

Penyalahgunaan wewenang dikenal dengan detournement de pouvoir yang ditujukan terhadap perbuatan aparat pemerintah yang sedang melaksanakan wewenangnya, tetapi tujuannya berbeda. Dengan kata lain penyalahgunaan wewenang terjadi, karena jika suatu wewenang dipergunakan tidak sesuai dengan maksud dan tujuan semula diberikannya wewenang tersebut menurut peraturan perundangundangan. ${ }^{42}$ Penyalahgunaan wewenang lazimnya berkaitan dengan tindakan yang tertentu seperti tindak pidana korupsi, dapat merugikan negara terutama perolehan negara dalam bidang keuangan. Argumentasi ini senada dengan pandangan Sjachran Basah bahwa perlindungan terhadap warga diberikan bilamana sikap tindak administrasi Negara itu menimbulkan kerugian terhadapnya. Sedangkan perlindungan terhadap administrasi Negara itu sendiri dilakukan terhadap sikap tindaknya dengan baik dan benar menurut hukum, baik yang tertulis maupun yang tidak tertulis. Lain kata, melindungi administrasi Negara dari melakukan perbuatan yang salah menurut hukum. ${ }^{43}$

\section{Tindak Pidana Korupsi dan Perbuatan Melawan Hukum}

Korupsi dalam sejarah manusia hadir bersamaan dengan manusia yang mulai hidup bermasyarakat disertai adanya beragam kebutuhan bertahan hidup yang kian menanjak, akan tetapi kesempatan dan sarana pemenuhannya semakin terbatas. Korupsi di Indonesia terjadi sejak zaman kerajaan dan perlu diketahui pula, bahwa VOC mengalami kebangkrutan pada awal abad 20 karena tindakan korupsi. ${ }^{44}$

40 W. M. Herry Susilowati, Tata Kelola Lembaga Penegak Hukum Tindak Pidana Korupsi di Indonesia, dalam Percikan Gagasan Tentang Hukum IV Mewujudkan Keadilan Sosial di Tengah Arus Perubahan Hukum, Sosial Budaya, Politik dan Ekonomi di Indonesia, Lustrum ke XI Fakultas Hukum Universitas Katolik Parahyangan, Bandung, 2013, hlm. 341.

41 Bagir Manan dan Kuntana Magnar, Beberapa Masalah Hukum Tata Negara Indonesia, Alumni Bandung, 1993, hlm. 128.

42 Sayuti, Relevansi Antara Maal Adm inistratif dan Upaya Penciptaan Good Governance, AL-RISALAH, Jurnal Kajian Hukum Islam, Volume 12 No. 1, Juni 2012, hlm. 13.

43 Sjachran Basah, Perlindungan Hukum terhadap Sikap Tindak Administrasi Negara, Orasi Ilmiah pada Dies Natalies XXIX Universitas Padjadjaran, 24 September 1986, hlm. 7. 
Bank Dunia menggambarkan tindak sebagai kejahatan terhadap kemanusiaan. Hal pidana korupsi merupakan penyalahangunaan wewenang yang dilakukan oleh pejabat ini karena dampak korupsi adalah hilangnya kesadaran rakyat banyak tentang hak mereka atau pemilik kekuasaan untuk kepentigan pribadi, korupsi memiliki kecenderungan sebagai warga negara dan ketidakpeduliannya kepada sistem kenegaraan suatu bangsa. Akibat memanfaatkan dana masyarakat yang seharusnya digunakan untuk mendapatkan penghidupan yang baik dan layak bagi lainnya adalah, korupsi betapun kecilnya, akan menghambat laju perekonomian. ${ }^{46}$

Korupsi di Indonesia, dapat dinobatkan mereka. ${ }^{45}$ Kecenderungan ini mengarahkan pada pandangan bahwa korupsi merupakan sebagai "biang kemudaratan", yang dapat meluluhlantakkan hampir semua bidang perbuatan yang dengan sadar mencederai kehidupan, seperti ekonomi, politik, hukum hak-hak yang seharusnya diterima oleh (mafia hukum/peradilan), sosial, budaya, masyarakat, karena kewajiban masyarakat kesehatan, pertanian, dan hankam, bahkan telah dipenuhi yaitu dengan membantu kehidupan beragamayang selama ini dianggap keuangan negara melalui dana aspirasi sebuah zona sakral dan sarat dengan nuansa mereka, bahkan ada yang menyatakan korupsi moral dan agamis, ternyata bersarang pula

44 Maria Ulfah, Bentuk Sanksi-sanksi Pidana bagi Pelaku Tindak Pidana Korupsi di Indonesia, dalam Percikan Gagasan Tentang Hukum IV Mewujudkan Keadilan Sosial di Tengah Arus Perubahan Hukum, Sosial Budaya, Politik dan Ekonomi di Indonesia, Lustrum ke XI Fakultas Hukum Universitas Katolik Parahyangan, Bandung, 2013, hlm. 86.

45 Alexandra M. Abboud (ed), Transforming The Culture Of Corruption, Journal Issues of Democracy, Volume 11 Number 12, 2006, page 1. Secara etimologis kata "Tindak Pidana" dan "Korupsi" berasal dari kata:

1. Istilah "Tindak Pidana" merupakan istilah teknis-yuridis dari kata bahasa Belanda "Stafbaar feit" atau "Delict" dengan pengertian perbuatan yang dilarang oleh peraturan hukum pidana dan tentu saja dikenakan sanksi pidana bagi siapa saja yang melanggarnya. Dalam kepustakaan ilmu hukum pidana istilah "Stafbaar feit" atau "Delict" ini ada yang menerjemahkan dengan istilah-istilah:

a. Peristiwa Pidana (Pasal 14 ayat (1) KRIS dan Undang-Undang Dasar Sementara 1950).

b. Perbuatan Pidana, Moeljatno, Perbuatan Pidana dan Pertanggungan Jawab Pidana (Pidana Dies Natalis UGM VI di Yogyakarta, 1955), Gajahmada, hlm. 9.

c. Perbuatan yang Boleh Dihukum, Mr. Kami, Ringkasan tentang Hukum Pidana, Balai Bukum Indonesia, Jakarta, 1959, hlm. 34.

d. Pelanggaran Pidana, MH. Tirtaamidjaja, Pokok-pokok Hukum Pidana, Fasco, Jakarta, 1955, hlm. 18.

2. Korupsi dalam bahasa Latin disebut Corruptio - corruptus, dalam bahasa Belanda disebut corruptie, dalam Bahasa Inggris disebut corruption, dalam bahasa Sansekerta didalam Naskah Kuno Negara Kertagama tersebut corrupt arti harfiahnya menunjukkan kepada perbuatan yang rusak, busuk, bejat, tidak jujur yang disangkutpautkan dengan keuangan. Sudarto, Hukum dan Hukum Pidana, Alumni, Bandung, 1996, hlm. 115. Istilah korupsi dalam Islam identik dengan riswah (suap) dan penyalahgunaan wewenang, korupsi termasuk kejahatan terhadap harta benda manusia dan secra esensial mirip ghulul yaitu pengkhianatan terhadap amanah dalam pengelolaan harta rampasan perang (ghanimah). Ghulul dengan jelas diharamkan Al Quran dan pelakunya akan dimintakan pertanggungjawaban di akhirat atas perbuatannya tersebut. Ahmad Diaudin Anwar, Penerapan Hukuman Mati bagi Pelaku Tindak Pidana Korupsi dalam Perpektif Hukum Islam, Skripsi pada Fakultas Syari'ah dan Hukum Universitas Islam Negeri (UIN) Sunan Kalijaga, Yogyakarta, 2010, Tidak dipublikasikan, hlm. 13-14.

46 Mansyur Semma, Negara dan Korupsi: Pemikiran Mochtar Lubis Atas Negara, Manusia Indonesia dan Perilaku Politik, Yayasan Obor Indonesia, Jakarta, 2008, hlm. 203. 
perilaku "amoral". Dampaknya, sangat besar dan meluas, mulai dari kerugian yang diderita oleh negara sampai pada fenomena meluasnya kemiskinan secara struktural di dalam masyarakat. Akibatnya, korupsi melahirkan berbagai tragedi alami, kemasyarakatan dan juga kemanusiaan. ${ }^{47}$

Secara yuridis, yang dimaksud dengan tindak pidana korupsi mencakup perbuatan (1) merugikan keuangan Negara dengan cara melawan hukum atau penyalahgunaan wewenang (Pasal 2 dan Pasal 3). (2) suap (Pasal 5, 6, 11, 12 huruf a,b,c,d, dan Pasal 13), (3) penggelapan dalam jabatan (Pasal 8 dan Pasal 10), (4) pemerasan (Pasal 12 huruf e,f,g), (5) perbuatan curang (Pasal 7 dan Pasal 12 huruf h), (6) konflik kepentingan dalam pengadaan (Pasal 12 huruf i) dan (7) gratifikasi (Pasal 12 B dan 12 C). ${ }^{48}$

Arvind K. Janin ${ }^{49}$ membagi korupsi kepada tiga jenis yaitu: grand corruption, bereaucratic corruption, legislative corruption.

Grand corruption, secara umum korupsi jenis ini merupakan tindakan yang dilakukan elit politik dengan menggunakan kekuasan yang dimiliki mereka untuk membuat berbagai kebijakan ekonomi. Elit politik yang korup memiliki kecenderungan untuk melakukan berbagai macam perubahan dalam kebijakan nasional atau pelaksanaannya, baik untuk kepentingan/keuntungan pribadinya yang berdampak kepada kerugian masyarakat pada umumnya.

Bereaucratic corruption, korupsi lahir dari berbagai perbuatan yang dilakukan oleh para birokrat yang mengadakan kesepakatankesepakatandenganparapejabatyangmemiliki wewenang dan melibatkan masyarakat untuk ikut serta dalam suatu tindak pidana korupsi. ${ }^{50}$ Perilaku suap merupakan cara yang lazim untuk dilakukan demimemperoleh pelayanan atau mempercepat proses birokrasi, upaya suap ini dapat pula terjadi pada lembaga peradilan yang ditujukan untuk meringankan atau mengurangi hukuman/pidana yang dijatuhkan.

Legislative corruption, ditujukan untuk mempengaruhi perilaku para anggota legislatif dalam pengambilan keputusan yang menggunakan cara voting (pemungutan suara terbanyak). Tipe korupsi ini dinamakan votebuying, baik dilakukan agar dirinya terpilih kembali atau dilakukan oleh pejabat eksekutif sebagai bagian dari usaha untuk mendorong penetapan terhadap suatu undang-undang.

Senada dengan Arvind K. Janin,

47 Widiada Gunakaya, Wanprestasi sebagai Kualifikasi tidak Dipenuhinya Kewajiban Hukum yang Menimbulkan Kerugian Keuangan Negara, Kajian Putusan Nomor 1247/Pid/B/2009/PN.Bdg, Jurnal Yudisial, Volume 5 No. 2, Agustus 2012, hlm. 190.

48 Amiruddin, Analisis Pola Pemberantasan Korupsi dalam Pengadaan Barang/Jasa Pemerintah, Jurnal Kriminologi Indonesia, Volume 8 No.1, Mei 2012, hlm. 27.

49 Arvik K. Janin, Corruption: A Review, Jornal of Economic Surveys, Blackwell Publisher ltd, Oxford, 2001, page 73-75.

50 Petty corruption merupakan nama lain dari jenis korupsi ini. 
Ermansjah Djaja membagi korupsi menjadi 4 (empat) jenis, yaitu sebagai berikut: ${ }^{51}$

1. Discretionery corruption, ialah korupsi yang dilakukan karena adanya kebebasan dalam menentukan kebijaksanaan, sekalipun nampaknya bersifat sah, bukanlah praktik-praktik yang dapat diterima oleh para anggota organisasi.

2. Illegal corruption, ialah suatu jenis tindakan yang bermaksud mengacaukan bahasa atau maksud-maksud hukum, peraturan dan regulasi tertentu.

3. Mercenary corruption, ialah jenis tindak pidana korupsi yang dimaksud untuk memperoleh keuntungan pribadi, melalui penyalahgunaan wewenang dan kekuasaan.

4. Ideological corruption, ialah jenis korupsi illegal maupun discretionery yang dimaksudkan untuk mengejar tujuan kelompok.

Kategori-kategori ini mengindikasikan korupsi merupakan perbuatan yang hanya dapat dilakukan oleh pemilik kewenangan dan kekuasaan, dengan cara-cara yang sistematis dan dianggap dapat dibenarkan karena berlindung kepada proses atau prosedur birokrasi dalam bidang politik, ekonomi bahkan hukum menjadi bagian dari proses pembenaran itu. Korupsi pada wilayah politik diarahkan untuk mempertahankan kekuasaan, korupsi pada wilayah ekonomi diarahkan untuk mempertahankan keuntungankeuntungan ekonomi yang didapat oleh pemilik kekuasaan, korupsi pada wilayah hukum diarahkan kepada manipulasi aturan hukum yang menjerat pemilik kekuasaan karena tindakannya digolongkan sebagai suatu tindak pidana korupsi. ${ }^{52}$

Robert Klitgaard secara kritis menggambarkan dengan jelas bagaimana kewenangan dan kekuasaan memiliki pengaruh yang begitu besar terhadap perilaku koruptif dalam tindak pidana korupsi.

"Korupsi ada apabila seseorang secara tidak sah meletakkan kepentingan pribadi di atas kepentingan masyarakat dan sesuatu yang dipercayakan kepadanya untuk dilaksanakan. Korupsi muncul dalam berbagai bentuk dan dapat bervariasi dari yang kecil sampai monumental. Korupsi dapat melibatkan penyalahgunaan perangkat kebijaksanaan, ketentuan tarif, dan perkreditan, kebijakan sistem irigasi dan perumahan, penegakan

51 Maryanto Pemberantasan Korupsi sebagai Upaya Penegakan Hukum, Jurnal Ilmiah CIVIS, Volume II No. 2, Juli 2012, hlm. 2.

52 Fenomena korupsi kini tidak hanya terjadi secara sentralistik di pusat pemerintahan semata. Dalam laporan Pusat Kajian Anti-Korupsi Universitas Gadjah Mada disebutkan bahwa dari 30 (tiga puluh) kasus korupsi pada semester I selama tahun 2008, tercatat yang paling banyak kasus didominasi oleh pejabat pemerintah daerah (16 (enam belas) orang). Setelah itu baru dilakukan oleh pejabat Badan Usaha Milik Negara (BUMN.) sebanyak 13 (tiga belas) orang, dan pengusaha swasta 11 (sebelas) orang. ("Pejabat Pemerintah Daerah Paling Korup", Sinar Harapan: 14 Agustus 2008). Tindak pidana korupsi yang menjadi kajian dalam analisis ini adalah tindak pidana korupsi yang dilakukan oleh terdakwa dalam kapasitasnya sebagai Kepala Badan Lingkungan Hidup dan Tata Kota Kabupaten Gunung Mas dan juga berkedudukan sebagai Pengguna Anggaran pada Badan Lingkungan Hidup Kabupaten Gunung Mas Tahun Anggaran 2007. (Deni Bram, Peran Hermeneutika dalam Rangka Meningkatkan Kualitas Putusan, Kajian Putusan Hakim Nomor 31/ Pid.B/2009/PN.PL.R, Jurnal Yudisial, Volume IV No. 01, April 2011, hlm. 53. 
hukum dan peraturan berkaitan dengan keselamatan umum, pelaksanaan kontrak dan pelunasan pinjaman atau melibatkan prosedur yang sederhana. Hal itu dapat terjadi pada sektor swasta atau sektor publik dan sering terjadi dalam kedua sektor tersebut secara simultan. Hal itu dapat jarang atau meluas terjadinya, pada sejumlah negara yang sedang berkembang, korupsi telah menjadi sistemik. Korupsi dapat melibatkan janji, ancaman atau keduanya; dapat dimulai oleh seorang pegawai negeri atau masyarakat yang berkepentingan, dapat mencakup perbuatan tidak melakukan atau melakukan; dapat melibatkan pekerjaan yang tidak sah maupun yang sah; dapat di dalam ataupun di luar organisasi publik. Batas-batas korupsi sangat sulit didefinisikan dan tergantung pada hukum lokal dan adat kebiasaan". 53

Selo Sumardjan lebih lanjut mengungkapkan bahwa korupsi menjadi suatu perilaku negatif yang dekat dengan penguasan dan kekuasaan, karena faktor-faktor sosial yang mengarahkan terbentuknya perilaku tersebut, dan perilaku negatif ini dianggap menjadi sesuatu yang wajar dilakukan oleh penguasa. faktor-faktor sosial tersebut yaitu:

1. Disintegrasi anomie sosial karena perubahan sosial terlalu cepat sejak revolusi nasional, dan melemahnya batas milik Negara dan milik pribadi;

2. Fokus budaya bergeser, nilai utama orientasi sosial beralih menjadi orientasi harta. Kaya tanpa harta menjadi kaya dengan harta;

3. Pembangunan ekonomi menjadi panglima pembangunan bukan pembangunan sosial atau budaya;

4. Penyalahgunaan kekuasaan Negara menjadi sebagai short cut mengumpulkan harta;

5. Paternalisme, korupsi tingkat tinggi, menyebar, meresap dalam kehidupan masyarakat. Bodoh kalau tidak menggunakan kesempatan kaya;

6. Pranata-pranata sosial sudah tidak efektif lagi. ${ }^{54}$

Sifat negatif korupsi begitu tampak jelas dapat mempengaruhi kehidupan masyarakat dalam pergaulannya, baik itu dalam bidang sosial kemasyarakatan, sosial ekonomi, sosial politik bahkan sosial hukum. Penampakan yang terlihat jelas itu coba di uraikan oleh Gunnar Myrdal dengan ungkapan-ungkapan sebagai berikut:

Pertama, Korupsi memantapkan dan memperbesar masalah-masalah yangmenyangkut kurangnya hasrat untuk terjun di bidang usaha dan kurang tumbuhnya perasaan nasional.

Kedua, Korupsi mempertajam permasalahan masyarakat plural, sedang bersamaan dengan itu kesatuan negara bertambah lemah. Juga karena turunnya

53 Ridwan, Kebijakan Formulasi Hukum Pidana dalam Penanggulangan Tindak Pidana Korupsi, Tesis pada Fakultas Hukum Universitas Diponegoro, Semarang, 2010, Tidak dipublikasikan, hlm. 41.

54 Evi Hartati, Op.cit., hlm. 16. 
martabat Pemerintah, tendensi-tendensi demikian membahayakan stabilitas politik;

Ketiga, Korupsi mengakibatkan turunnya disiplin sosial. Uang suap tidak hanya dapat memperlancar prosedur administrasi, tetapi biasanya juga berakibat adanya kesengajaan untuk memperlambat proses administrasi agar dengan demikian dapat menerima uang suap. Disamping itu, pelaksanaan rencana-rencana pembangunan yang sudah diputuskan, dipersulit, atau diperlambat karena alasanalasan sama. ${ }^{55}$

Kondisi tersebut tentu bukan tanpa alasan, karena menurut Koentjoroningrat, salah satu ciri mental manusia Indonesia adalah sikapuntuk mencapai tujuan secepatnya, tanpa banyak kerelaan untuk berusaha secara selangkah demi selangkah. sikap mental inilah yang kemudian mendorong para penyelenggara negara atau tepatnya penegak hukum untuk melakukan tindakan tidak terpuji yaitu suap. ${ }^{56}$ Seiring dengan pendapat tersebut, Umi Kulsum berpendapat bahwa tindak pidana korupsi di Indonesia merupakan perbuatan yang telah mengakar dalam berbagai sendi kehidupan manusia, sehingga seolah-olah dianggap sebagai budaya. ${ }^{57}$

Sikap mental ini harus dimaknai bukan sebagai budaya asli manusia, terutama manusia Indonesia sebagai makhluk Tuhan yang di dalam dirinya mengandung nilai-nilai kebaikan yang begitu besar dan mendalam, dibandingkan nilai-nilai keburukan yang mengarahkan dirinya untuk berbuat jahat dalam upaya pencapaian kehendak, kepentingan maupun keuntungan pribadinya tanpa mengindahkan nilainilai kemanusiaannya. Tuhan dengan jelas mengarahkan manusia untuk selalu berbuat baik dan melepaskan godaan-godaan yang mengarahkan dirinya untuk berbuat jahat dan kejahatan yang dapat merugikan manusia, karena kejahatan tidak hanya dapat merugikan diri pelaku melainkan dapat memberikan imbas yang luas bagi masyarakat secara keseluruhan.

Francis Fukuyama mengungkapkan pendapat yang mengarahkan pandangan bahwa budaya lahir dan berkembang selalu menuju arah yang baik dan lebih baik, dengan jelas dikatakan bahwa budaya adalah suatu kebiasaan baik yang diturunkan secara turun menurun (inherited ethical habit), ungkapan ini diutarakan untuk menunjukkan bahwa korupsi bukanlah budaya melainkan suatu perilaku anti budaya (anti kebiasaan baik yang seharusnya menjadi perilaku yang dapat diwariskan secara turun-menurun). ${ }^{58}$

55 Djoko Prakoso dkk, Kejahatan-kejahatan yang Membahayakan dan Merugikan Negara, Bina Aksara, Jakarta, 2007, hlm. 395.

56 Satjipto Rahardjo, Membangun dan Merombak Hukum Indonesia, Sebuah Pendekatan Lintas Disiplin, Genta Publishing, Yogyakarta, 2009, hlm. 6.

57 Umi Kulsum, Kewenangan Komisi Pemberantasan Korupsi (KPK) dalam Melakukan Pemberantasan Tindak Pidana Korupsi, Jurnal Jure Humano, Volume 1 No. 3, 2009, hlm. 81.

58 Ridwan, Op.cit., hlm. 61. 
Korupsi timbul tidak serta merta melainkan Darus Badrulzaman, Sri Soedewi memerlukan unsur atau faktor pendukung, agar suatu perbuatan dapat dikatakan sebagai tindak pidana korupsi. Perbuatan melawan hukum atau onrechtmatigedaad merupakan salah satu unsur tersebut. Arti sempit perbuatan melawan hukum sama dengan perbuatan melawan undang-undang (onrechtmatig sama dengan onwetmatig). Sedangkan dalam pengertian luas, perbuatan melawan hukum termasuk memperkosa hak orang lain, atau bertentangan dengan kewajiban hukum si pembuat, atau bertentangan dengan kesusilaan, atau dengan kepatutan (kepantasan) dalam hidup bermasyarakat. Pengertian secara luas ini memberikan unsurunsur untuk adanya perbuatan melawan hukum, yaitu: melanggar suatu hak orang lain, melanggar kewajiban hukum si pelaku perbuatan tersebut, melanggar kesusilaan, dan melanggar kepatutan/kepantasan yang berlaku dalam masyarakat terhadap orang atau barang milik orang lain. ${ }^{59}$

Terminologi perbuatan melawan hukum merupakan terjemahan dari kata onrechtmatige daad (bahasa Belanda) atau dalam bahasa Inggris dikenal dengan istilah 'tort'. Wirjono Projodikoro, menerjemahkan kata onrechtmatige daad kekuasaan sudah melanggar sesuatu hak menjadi 'perbuatan melanggar hukum'. dengan kekuasaan sehingga menimbulkan M.A. Moegni Djojodordjo, Mariam kerugian pada B, maka telah "melawan" tanpa

59 Muchsan, Sistem Pengawasan terhadap Perbuatan Aparat Pemerintah dan Peradilan Tata Usaha Negara di Indonesia, Liberty, Yogyakarta, 2000, hlm. 15.

60 Rosa Agustina, Perbuatan Melawan Hukum, dalam Hukum Perikatan (Law of Obligations), Pustaka Larasan Denpasar atas kerjasama antara Universitas Indonesia, Universitas Leiden dan Universitas Groningen, 2012, hlm. 3 . 
harus menggerakkan badannya, inilah sifat pasif dan pada istilah "melawan". ${ }^{61}$

Perbuatan melawan hukum dalam konteks korupsi mencakup formil dan materil. Istilah melawan hukum (wederrechtelijk) dalam literatur hukum pidana masih dikenal pengertian melawan hukum yang saling berbeda seperti, bertentangan dengan hukum, bertentangan dengan hak orang lain, tanpa hak sendiri. ${ }^{62}$

Hak dalam pengertian hukum diberikan beberapa karakteristik, yaitu: ${ }^{63}$

1. Melekat ada seseorang. Orang ini disebut sebagai pemilik hak (the owner of the right) atau pemegang hak (the subject of it, the person entitled, or the person inherence).

2. Seseorang yang terkena oleh hak itu itu terikat oleh suatu kewajiban tertentu. Orang ini disebut memiliki kewajiban (the person bound to) atau subjek dari kewajiban (the subject of duty atau person of incidence)

3. Hak ini mewajibkan seseorang untuk melakukan atau tidak melakukan suatu perbuatan bagi kepentingan pemegang hak. Inilah yang merupakan suatu hak.

4. Melakukan atau tidak melakukan perbuatan tadi berkaitan dengan suatu objek tertentu (object or the subject matter of the right).

5. Setiap hak memiliki fakta-fakta atau peristiwa-peristiwa yang atas dasar itu hak tersebut melekat pada seseorang.

Unsur melawan hukum mempunyai makna yang luas terkait dengan perbuatan atau tindakan yang mengarahkan akibat kesengajaan ataupun kelalaiannya, menyebabkan terlanggar atau dilanggarnya hak seseorang, bertentangan dengan kewajiban sendiri menurut hukum atau norma adat kesopanan yang lazim, atau bertentangan dengan keharusan pergaulan hidup untuk bertindak prihatin terhadap orang lain atau barangnya. ${ }^{64}$

Sifat melawan hukum merupakan unsur yang mendapat perhatian khusus dalam tindak pidana, keberadaan unsur sifat melawan hukum dalam pengertian tindak pidana bahkan tidak terpengaruh terhadap apakah pengertian tersebut dihasilkan oleh sarjana yang menganut aliran monisme ataupun dualisme sebagaimana dapat dilihat dalam bahasan tindak pidana sebelumnya. Urgensi sifat melawan hukum bertolak dari kenyataan bahwa yang menjadi perhatian hukum pidana adalah perbuatan-perbuatan yang bersifat melawan hukum saja, perbuatan-perbuatan tersebutlah yang kemudian dalam hukum pidana dilarang dan diancam dengan pidana ${ }^{65}$

61 Anonim.

62 Indroharto dkk, Kapita Selekta Hukum dalam Mengenang Prof. H. Oemar Seno Adji, Ghalia Indonesia, Jakarta, 1996, hlm. 57.

63 Lili Rasjidi, Filsafat Hukum, Apakah Hukum Itu?, Rosdakarya, Bandung, 1991, hlm. 68-69.

64 Yenti Garnasih dkk, Benang Kusut Peradilan Korupsi Perbankan Catatan Hasil Eksiminasi Putusan Neloe dkk, KHRN, Jakarta, 2006, hlm. 51.

65 Dwiki Oktobrian, Politik Kriminal Penanggulangan Tindak Pidana Korupsi di Indonesia pada Era Reformasi, Skripsi pada Fakultas Hukum Universitas Jenderal Soedirman, Purwokerto, 2013, Tidak dipublikasikan, hlm. 25. 
Khusus mengenai sifat melawan hukum, dalam literatur ilmu hukum pidana paling tidak terdapat 2 (dua) hal yaitu sifat melawan hukum formil dan sifat melawan hukum materilyang diartikan Apabila perbuatan tindak pidana yang dimaksudkan dirumuskan sebagai wujud perbuatan tanpa menyebutkan akibat yang disebabkan oleh perbuatan itu, inilah yang disebut dengan sifat melawan hukum formil. Sifat melawan hukum materiel adalah sebagai suatu perbuatan yang telah ditentukan dalam hukum pidana (straf) dan dirumuskan sebagai perbuatan yang menyebabkan suatu akibat tertentu, tanpa merumuskan wujud dari perbuatan itu. ${ }^{66}$

Sifat melawan hukum formil ini Enschede memandang bahwa hukum pidana hanyalah rumusan delik, yang menunjukkan fragmenfragmen dari norma-norma yang berkaitan dengan suatu tindakan yang dapat dipidana. ${ }^{67}$ sedangkan menurut P.A.F. Lamintang adalah suatu perbuatan hanya dapat dipandang sebagai bersifat "melawan hukum" apabila perbuatan tersebut memenuhi unsur yang terdapat di dalam rumusan suatu delik menurut undang-undang. ${ }^{68}$

Prinsip kesetaraan/persamaan merupakan acuan dari melawan hukum dalam arti formil bilamana setiap orang, tanpa membedabedakan latarbelakangnya, mendapatkan perlakuan yang sama. Sebaliknya kita berbicara tentang kesetaraan materiil bilamana orang-perorang mendapatkan perlakuan yang sama sesuai dengan tingkatan kebutuhan atau kedudukannya. Interpretasi formil memandang manusia terutama sebagai subjek hukum, pengemban hak dan kewajiban berdasarkan hukum, namun terlepas atau dilepaskan dari keragaman latarbelakangnya. Interpretasi materiil juga memandang manusia sebagai subjek hukum. ${ }^{69}$

UU No. 31 Tahun 1999 menetapkan ajaran sifat melawan hukum materiil, dirumuskan di dalam perihal "Menimbang” pada huruf a dan Penjelasan Umum dari UU dimaksud, yaitu: "Bahwa tindak pidana korupsi yang selama ini terjadi secara meluas, tidak hanya merugikan keuangan negara, tetapi juga telah merupakan pelanggaran terhadap hak-hak sosial dan ekonomi masyarakat secara luas, sehingga tindak pidana korupsi perlu digolongkan sebagai kejahatan yang pemberantasannya harus dilakukan secara luar biasa. Yakni meskipun perbuatan tersebut tidak diatur dalam perundang-undangan namun apabila perbuatan tersebut dianggap tercela karena

66 Anonim. Tindak pidana korupsi berdasarkan Putusan Mahkamah konstitusi Nomor: 003/PUU-IV/2006 tentang pembatalan penjelasan Pasal 2 ayat (1) Undang-undang Nomor 31 Tahun 1999 tentang pemberantasan tindak pidana korupsi merupakan tindak pidana yang menekankan pada perbuatannya saja (delik formil) tidak pada akibatnya (telah terjadi kerugian negara), dengan berpegang pada putusan Mahkamah Konstitusi tersebut maka kerugian Negara tidah harus dibuktikan terlebuh dahulu.

67 Barda Nawawi Arief, Beberapa Aspek Kebijakan Penegakan dan Pengembangan Hukum Pidana, Citra Aditya Bakti, Bandung, 2005, hlm. 29.

68 P.A.F. Lamintang, Dasar-dasar Hukum Pidana Indonesia, Citra Aditya Bakti, Bandung, 1997, hlm. 351

69 Jeoroen ten Voorde, Hukum Pidana dalam Masyarakat Pluralistik, dalam Hukum Pidana Dalam Perpektif, Pustaka Larasan Denpasar atas kerjasama antara Universitas Indonesia, Universitas Leiden dan Universitas Groningen, 2012, hlm. 20. 
tidak sesuai dengan rasa keadilan atau normanorma kehidupan dalam masyarakat, maka perbuatan tersebut dapat dipidana. ${ }^{70}$

Sifat melawan hukum materil Sudarto berpendapat bahwa suatu perbuatan itu melawan hukum atau tidak, tidak hanya yang terdapat dalam undang-undang (yang tertulis) saja, akan tetapi harus dilihat berlakunya asasasas hukum yang tidak tertulis. Jadi menurut ajaran ini melawan hukum sama bertentangan dengan undang-undang (hukum tertulis) dan juga bertentang dengan hukum yang tidak tertulis termasuk tata susila dan sebagainya. Jika diperhatikan maka, sifat melawan hukum materiil tersebut indentik dengan sebuah kejahatan atau rechdelict yang menurut Sudarto adalah perbuatan yang bertentangan keadilan, terlepas apakah perbuatan diancam pidana dalam suatu undang-undang atau tidak, jadi yang benar-benar dirasakan oleh masyarakat sebagai bertentangan dengan rasa keadilan. ${ }^{71}$

Pengertian sifat melawan hukum secara materiil dalam arti positif akan merupakan pelanggaran asas legalitas, pada Pasal 1 ayat 1 KUHP, artinya ajaran sifat melawan hukum dalam fungsi positif yaitu meskipun suatu perbuatan secara materiil merupakan perbuatan melawan hukum apabila tidak ada aturan tertulis dalam perundang-undangan pidana, perbuatan tersebut tidak dapat dipidana. Ajaran sifat melawan hukum materiil hanya diterima dalam fungsinya yang negatif, dalam arti bahwa suatu perbuatan dapat hilang sifatnya sebagai melawan hukum, apabila secara materiil perbuatan itu tidak bertentangan dengan hukum. ${ }^{72}$

Perbuatan melawan hukum dalam makna formil dan materil pada tindak pidana korupsi, merupakan satu kesatuan yang tidak dapat dipisahkan. Formil dijadikan sebagai landasan untuk menentukan suatu perbuatan dapat dikategorikan sebagai suatu perbuatan korupsi, dengan dasar bahwa perbuatan tersebut telah dalam aturan hukum terutama undang-undang. Materil mengarahkan pada landasan bahwa suatu kejahatan dapat dikatakan sebagai suatu tindak kejahatan, yang berada dalam ruang lingkup tindak pidana korupsi dengan ditunjukkan bahwa perbuatan itu dapat mengakibatkan dampak yang luas terhadap keberlangsungan hidup masyarakat yang berkaitan dengan kesejahteraan dan kemakmuran.

70 Widiada Gunakarya, Op.cit., hlm. 21.

71 Sudarto, Hukum Pidana I, Yayasan Soedarto, Semarang, 1990, hlm. 78 dan 56.

72 Ninil Eva Yustina, Perbuatan Melawan Hukum Materiil (Materiel Wederrechtelijkeheid) dalam Tindak Pidana Korupsi pada Praktik Peradilan Indonesia Pasca Putusan Mahkamah Konstitusi, Rangkuman Tesis pada Fakultas Hukum Universitas Merdeka, Malang, 2009, Tidak dipublikasikan, hlm. 4. 


\section{Simpulan}

1. Korupsi memiliki dua perlekatan pada perbuatan melawan hukum yaitu formal dan material, kedua perlekatan tersebut dapat dijadikan dasar untuk meminta pertanggungjawaban bagi pelaku tindak pidana korupsi, baik perbuatan tersebut dilakukan oleh masyarakat atau pun oleh pemegang kewenangan dan kekuasaan yang notabene merupakan pejabat publik, karena kecenderungan untuk memperoleh kekuasaan dan keuntungan ekonomi.

2. Perbuatan melawan hukum dapat menjadi dasar pertanggungjawaban dengan menempatkan tanggungjawab perdata yang berkaitan dengan kerugian akibat tindak pidana korupsi, tanggungjawab pidana yang berkaitan dengan pelanggaran terhadap undang-undang dan pelanggaran terhadap hak orang lain, serta tanggungjawab adminsitrasi yang berkaitan dengan penyalahangunaan wewenang dan kekuasaan, sebagai acuan bahwa tindak pidana korupsi merupakan perbuatan yang ditujukan hanya demi memperoleh keuntungan pribadi bagi golongan tertentu baik secara ekonomi maupun secara politik.

\section{DAFTAR PUSTAKA}

Buku

Barda Nawawi Arief, 2005, Beberapa Aspek Kebijakan Penegakan dan Pengembangan Hukum Pidana, Citra Aditya Bakti, Bandung.

Djoko Prakoso dkk, 2007, Kejahatankejahatan yang Membahayakan dan Merugikan Negara, Bina Aksara, Jakarta.

Eggi Sudjana, 2008, Republik tanpa KPK

Koruptor Harus Mati, JP Books, Surabaya.

Endang Saefullah Wiradipraja, 1996,

Tanggungjawab Pengangkut dalam

Hukum Udara, Balai Pustaka, Jakarta. , 2008, Hukum Transportasi

Udara: dari Warsawa 1929 ke
Monteral 1999, Kiblat Utama, Bandung.

Evi Hartanti, 2009, Tindak Pidana Korupsi, Sinar Grafika, Jakarta.

Indroharto dkk, 1996, Kapita Selekta Hukum dalam Mengenang Prof. H. Oemar Seno Adji, Ghalia Indonesia, Jakarta.

Ishaq, 2009, Dasar-dasar Ilmu Hukum, Sinar Grafika, Jakarta.

J. Satrio. 1993, Hukum Perikatan (Perikatan yang Lahir dari undang-undang), Citra Aditya Bakti, Bandung.

Jeoroen ten Voorde, 2012, Hukum Pidana dalam Masyarakat Pluralistik, dalam Hukum Pidana Dalam Perpektif, Pustaka Larasan Denpasar atas 
kerjasama antara Universitas Indonesia,

Universitas Leiden dan Universitas

Groningen.

Jimly Asshidiqie dan M. Ali Safa'at, 2011,

Teori Hans Kelsen tentang Hukum,

Konstitusi Press (Konpress), Jakarta.

Kami, 1959, Ringkasan tentang Hukum

Pidana, Balai Hukum Indonesia, Jakarta.

Komariah, 2001, Hukum Perdata,

Universitas Muhammadiyah Malang,

Malang.

Lili Rasjidi, 1991, Filsafat Hukum, Apakah

Hukum Itu?, Rosdakarya, Bandung.

MH. Tirtaamidjaja, 1955, Pokok-pokok

Hukum Pidana, Fasco, Jakarta.

Mansyur Semma, 2008, Negara dan

Korupsi: Pemikiran Mochtar Lubis

Atas Negara, Manusia Indonesia,

dan Perilaku Politik, Yayasan Obor

Indonesia, Jakarta.

Maria Ulfah, 2013, Bentuk Sanksi-

sanksi Pidana bagi Pelaku Tindak

Pidana Korupsi di Indonesia,

dalam Percikan Gagasan tentang

Hukum IV Mewujudkan Keadilan

Sosial di Tengah Arus Perubahan

Hukum, Sosial Budaya, Politik dan

Ekonomi di Indonesia, Lustrum ke XI

Fakultas Hukum Universitas Katolik

Parahyangan, Bandung.

Munir Fuady, 2000, Perbuatan Melawan

Hukum (Pendekatan Kontemporer), Citra Aditya Bekti, Bandung.
, 2005, Perbuatan Melawan

Hukum (Pendekatan Kontemporer),

Citra Aditya Bakti, Bandung.

P.A.F. Lamintang, 1997, Dasar-dasar Hukum

Pidana Indonesia, Citra Aditya Bakti, Bandung.

Peter Mahmud Marzuki, 2009, Penelitian Hukum, Kencana, Jakarta.

R. Achmad S. Soemadipraja, 1990, Hukum

Pidana dalam Yurisprudensi, Armico, Bandung.

Rachmat Setiawan, 1991, Tinjauan

Elementer Perbuatan Melawan

Hukum, Binacipta, Bandung.

Rosa Agustina dkk, 2012, Pengantar

Penulis, dalam Hukum Perikatan

(Law of Obligations), Pustaka Larasan

Denpasar atas kerjasama antara

Universitas Indonesia, Universitas

Leiden dan Universitas Groningen.

Rosa Agustina, 2012, Perbuatan Melawan

Hukum, dalam Hukum Perikatan

(Law of Obligations), Pustaka Larasan

Denpasar atas kerjasama antara

Universitas Indonesia, Universitas

Leiden dan Universitas Groningen.

Satjipto Rahardjo, 2009, Membangun dan

Merombak Hukum Indonesia,

Sebuah Pendekatan Lintas Disiplin,

Genta Publishing, Yogyakarta.

Sudarto, 1990, Hukum Pidana I, Yayasan

Soedarto, Semarang.

, 1996, Hukum dan Hukum Pidana,

Alumni, Bandung. 
Yenti Garnasih dkk, 2006, Benang Kusut Peradilan Korupsi Perbankan Catatan Hasil Eksiminasi Putusan Neloe dkk, KHRN, Jakarta.

\section{Skrpsi, Tesis dan Disertasi}

Ahmad Diaudin Anwar, 2010, Penerapan

Hukuman Mati bagi Pelaku Tindak

Pidana Korupsi dalam Perpektif

Hukum Islam, Skripsi pada Fakultas

Syari'ah dan Hukum Universitas

Islam Negeri (UIN) Sunan Kalijaga,

Yogyakarta, Tidak dipublikasikan.

Dwiki Oktobrian, 2013, Politik Kriminal

Penanggulangan Tindak Pidana

Korupsi di Indonesia Pada Era

Reformasi, Skripsi pada Fakultas

Hukum Universitas Jenderal Soedirman,

Purwokerto, Tidak dipublikasikan.

Irdanul Achyar, 2010, Analisis

Pengimplementasian Rezim Civil

Forfeiture dalam Pemberantasan

Money Laundering, Skripsi pada

Fakultas Hukum Universitas Sumatera Utara, Medan.

Kiki Nitalia Hasibuan, 2011, Perbuatan Melawan Hukum dalam Kasus Mis-Selling, Skripsi pada Fakultas Hukum Universitas Indonesia, Jakarta.

M. Masril, 2009, Mekanisme Penyelesaian Sengketa Konsumen terhadap Produk Cacat dalam Kaitannya dengan Tanggungjawab Produsen, Tesis Program Magister Ilmu Hukum pada Sekolah Pascasarjana Universitas Sumatera Utara, Tidak dipublikasikan.
Ninil Eva Yustina, 2009, Perbuatan Melawan Hukum Materiil (Materiel Wederrechtelijkeheid) dalam Tindak Pidana Korupsi pada Praktik Peradilan Indonesia Pasca Putusan Mahkamah Konstitusi, ringkasan Tesis pada Fakultas Hukum Universitas Merdeka, Malang.

Ridwan, 2010, Kebijakan Formulasi Hukum Pidana dalam Penanggulangan Tindak Pidana Korupsi, Tesis pada Fakultas Hukum Universitas Diponegoro, Semarang, Tidak dipublikasikan.

Rosa Agustina, 2003, Perbuatan Melawan

Hukum, Disertasi pada Fakultas Hukum Universitas Indonesia, Tidak dipublikasikan.

\section{Jurnal}

Ahmad Sudiro, 2012, Konsep Keadilan John

Rawls, Jurnal Legislasi Indonesia, Volume 19 No. 3 Juli 2012.

Alexandra M. Abboud (ed), 2006,
Transforming the Culture Of
Corruption, Journal Issues of
Democracy, Volume 11 Number 2.
Amiruddin, 2012, Analisis Pola Pemberantasan Korupsi dalam Pengadaan Barang/Jasa Pemerintah, Jurnal Kriminologi Indonesia, Volume 8 No.1, Mei 2012.

Arvind K. Janin, 2001, Corruption: A Review, Jornal of Economic Surveys, Blackwell Publisher 1td, Oxford. 
Deni Bram, 2011, Peran Hermeneutika dalam Rangka Meningkatkan Kualitas Putusan, Kajian Putusan Hakim Nomor 31/Pid.B/2009/ PN.PL.R, Jurnal Yudisial Volume IV No. 01, April 2011.

Henry P. Panggabean, 2013, Penegakan Hukum Tindak Pidana Korupsi Mendukung Pembangunan Hukum Berbasis Hak Asasi Manusia, Jurnal Legislasi IndonesiaVolume 10 No. 2, Juni 2013.

I. Gusti Ketut Ariawan, 2008, "Stolen Asset Recovery Initiative, Suatu Harapan dalam Pengembalian Aset Negara", Jurnal Kertha Patrika, Volume 33 No. 01, Januari 2008.

Loura Hardjaloka, 2012, Ketetapan Hakim dalam Penerapan Precautionary Principle Sebagai "Ius Cogen" dalam Kasus Gunung Mandalawangi (Kajian Putusan Nomor 1794K/ Pdt/2004), Jurnal Yudisial Volume 5 No. 2, Agustus 2012.

Maryanto, 2012, Pemberantasan Korupsi sebagai Upaya Penegakan Hukum, Jurnal Ilmiah CIVIS, Volume II No. 2, Juli 2012.

Ridwan Khairandy, 2011, Landasan Filosofis Kekuatan Mengikatnya Kontrak, Jurnal Hukum, No. Edisi khusus, Volume 18 oktober 2011.
Umi Kulsum, 2009, Kewenangan Komisi Pemberantasan Korupsi (KPK) dalam Melakukan Pemberantasan Tindak Pidana Korupsi, Jurnal Jure Humano, Volume 1 No. 3, 2009.

Widiada Gunakaya, 2012, Wanprestasi sebagai Kualifikasi Tidak Dipenuhinya Kewajiban Hukum yang Menimbulkan Kerugian Keuangan Negara (Kajian Putusan Nomor 1247/Pid/B/2009/PN.Bdg), Jurnal Yudisial Volume 5 No. 2, Agustus 2012.

\section{Makalah}

Bismar Nasution, 2007, "Stolen Asset Recavery Initiative dari Perspektif Hukum Ekonomi di Indonesia", Makalah disajikan dalam Seminar Pengkajian Hukum Nasional 2007 (SPHN 2007), Jakarta, 28 Nopember 2007.

Moeljatno, 1955, Perbuatan Pidana dan Pertanggungan Jawab Pidana, Dies Natalis UGM VI, Yogyakarta.

\section{Naskah Internet}

Hukum Online, "Yayasan Supersemar Resmi Digugat", "Perburuan Harta Mantan Presiden Soeharto Kembali Dimulai. Mungkinkah Berhasil?", http://www.hukumonline.com/detail. asp $\mathrm{id}=17123 \& \mathrm{cl}=$ Berita. 